\title{
GREEN DENSITY OPTIMISATION WITH SUSTAINABLE SEWAGE FAT AS BINDER COMPONENTS IN SS316L FEEDSTOCK OF METAL INJECTION MOULDING PROCESS (MIM) BY TAGUCHI METHOD
}

\author{
A.M Amin ${ }^{1 \mathrm{a}}$, M.H.I Ibrahim ${ }^{1 \mathrm{~b}}$, R. Asmawi ${ }^{1 \mathrm{c}}$, N. Mustapha ${ }^{1 \mathrm{~d}}$, M.Y Hashim $^{1 \mathrm{e}}$ \\ ${ }^{1}$ Faculty of Mechanical and Munufacturing Engineering, Universiti Tun Hussein Onn Malaysia, \\ 86400, Parit Raja, Batu Pahat, Johor.
}

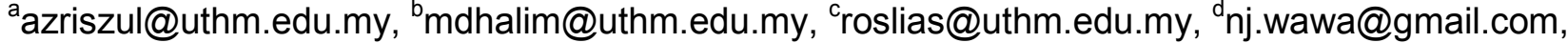 eyusni@uthm.edu.my

Keyword: Sewage Fat or Fat Oil Grease, Metal injection moulding, Taguchi method, Design of Experiment (DOE)

\begin{abstract}
Metal injection moulding has gain much attention due to flexibility and high productivity of the plastics injection moulding with the powder metallurgy method of sintering. In order to gain better shape retention, optimum density of green part is required. This paper deals with the application of Taguchi optimisation technique on getting the optimum density for Metal Injection Moulding (MIM) components base on certain parameters in process injection. For this purposes only 3 process parameters were considered here including its interactions which are injection pressure, injection temperature and mould temperature. Since its more close to the final products these parameters were selected and other parameters will be kept constant. An orthogonal array of L16 experimental base design was conducted. Confirmation test will be done base on Signal-toNoise $(\mathrm{S} / \mathrm{N})$ ratio and it Means.
\end{abstract}

\subsection{INTRODUCTION}

Sustainability development must not compromises the standards and health of future generations [1]. Efficiency of used natural resources with reduction of waste and emission through its usage are required. Existing industrial technologies in terms of materials, equipments and processes has help to create the high standard of living which much appreciated in world today is no longer appropriated (Evans et al., 2008 cited in [2]). As living of standards continuously rises, demand of products will also continue to increase which will affect manufacturing area whilst using less material, energy and generating less waste.

Metal injection moulding is a manufacturing process with an advantage of producing complex and intricate parts in high volume production with a few shot as compare to other fabrication process[3]-[5]. After being injected, the parts will undergo debinding process and finally sintering process.

The traditional approach to experimental work is to vary one factor at a time, holding all other factors fixed. This method does not produce satisfactory results in a wide range of experimental settings and when multiple performance characteristics with conflicting goals are considered, the approach becomes unsuitable [6]. Nowadays, optimization of the process parameter are gaining much interests among researchers as it can minimize defects, cost and obtain high efficiency in the planning or experiments. Numerous researchers like $\mathrm{Zu}$ and Lin [7] in their work of debinding of injection moulded for optimum mechanical properties have shown that principal factors that affecting it, is solvent debinding temperature and thermal debinding atmosphere. They used Taguchi Method in implemented the Design of Experiments (DOE) for finding the optimum process variables. Ibrahim et. al [6] use Taguchi method for optimizing the green density of injection moulded sample using variety factors like injection pressure, injection temperature, mold temperature, injection time and holding time. Interactions between the factors also being analysed for optimum green strength of the injection moulded sample. They founds that mold temperature, injection time and pressure are the significant factors that affect the green strength of the green sample. 
Therefore, Taguchi's parameter design, being a simple and inexpensive method, is adopted for in-depth study to understand process parameters and their interaction effects on responses like accuracy of dimensions and reducing the defects [8] with minimum experimental runs. Conventional Taguchi method can effectively establish optimal parameter settings for single performance characteristic[9]. Hence, Taguchi method $\left(\mathrm{L}_{16}\right)$ is used in this work to generate a single response which is green density of injection moulded sample which is important before undergo debinding process for optimum density.

\subsection{EXPERIMENTAL}

\subsection{Materials}

The properties of stainless steel powder with $60 \%$ powder loading used are shown in Table 1. Binder formulation used in this optimising process parameters is $60 \%$ to $40 \%$ between the polypropylene and sewage fat. This formulation is the optimum one since it has the highest mouldability index [10]. The properties of the binder constituents are shown in Table 2.

Table 1: Properties of SS316L powder

\begin{tabular}{cc}
\hline Identification & SS316L, PF-10F \\
\hline Powder source & Epson Atmix Corp \\
Tap density, $\mathbf{g} / \mathbf{c m}^{\mathbf{3}}$ & 4.06 \\
True pynometer density, $\mathbf{g} / \mathbf{c m}^{3}$ & 8.0471 \\
Powder size & $\mathrm{d}_{10}=2.87 \mu \mathrm{m}$ \\
& $\mathrm{d}_{50}=5.96 \mu \mathrm{m}$ \\
$\mathrm{d}_{90}=10.65 \mu \mathrm{m}$ & 10.65 \\
\hline
\end{tabular}

Table 2: Three different binder weight percentage with the same $62 \%$ powder loading

\begin{tabular}{lcc}
\hline \multicolumn{1}{c}{ Binder constituents } & Density $\left(\mathrm{g} / \mathrm{cm}^{3}\right)$ & $\mathrm{T}_{\mathrm{m}}\left({ }^{\circ} \mathrm{C}\right)$ \\
\hline Polypropylene, PP & $\mathbf{0 . 9}$ & 165 \\
Sewage fat & $\mathbf{0 . 9 0 1 5 6}$ & 50 \\
\hline
\end{tabular}

Injection moulding was carried out on a Nissei NP 7 Real Mini machine. Fig. 1 shows the MIM sample injected base on two level factors which are injection temperature, pressure and mould temperature with others factors are kept constant. Density of the injected parts being measured using pycnometer density.

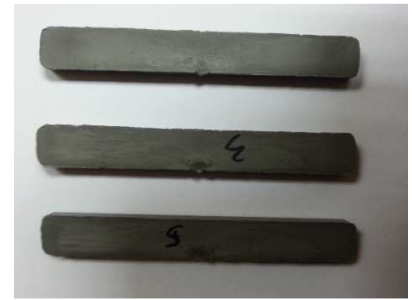

Figure 1: Sample injected

\subsection{Design of Experiments}

Taguchi $\left(\mathrm{L}_{16}\right)$ design of experiments is used in order to improve the green density of the injected samples. Nominal is best type of control function being used in calculating the $\mathrm{S} / \mathrm{N}$ ratio. Two level designs of experiments with 3 factors was considered in the injection moulding process with others factor are kept constant. The factors that are kept constant are shown in Table 3 . The parameters that made varies are injection temperature, pressure and mould temperature as shown in Table 4. Total degree of freedom (DOF) for single and interactions parameters is 7 and $\mathrm{L}_{16}$ 's Taguchi orthogonal array seems suitable for this analysis with 16 experiments will be conducted (Table 5).

$$
\frac{\mathrm{S}}{\mathrm{N}}=10 \log _{10} \sum \frac{\overline{\mathrm{y}}^{2}}{\sigma_{N-1}^{2}}
$$


Table 3: Factors and Levels of Injection Process

\begin{tabular}{|l|c|c|}
\hline \multicolumn{1}{|c|}{ Factor } & Level 1 & Level 2 \\
\hline Injection Temperature, $\mathrm{A}\left({ }^{\circ} \mathrm{C}\right)$ & 180 & 200 \\
\hline Injection Pressure, $\mathrm{B}(\mathrm{MPa})$ & 64 & 97 \\
\hline Mould temperature, $\mathrm{C}\left({ }^{\circ} \mathrm{C}\right)$ & 60 & 80 \\
\hline
\end{tabular}

The column assignment and experimental layout are shown in table 5 with each experiment was conducted with two replications. After completion the all experiments and analysis of the data, the recommendation setting will be tested.

Table 4: Experimental layout of Taguchi $\left(L_{16}\right)$

\begin{tabular}{|c|c|c|c|c|}
\hline \multicolumn{3}{|c|}{ Factors } & \multicolumn{2}{|c|}{ Density $\left(\mathrm{g} / \mathrm{cm}^{3}\right)$} \\
\hline $\begin{array}{c}\text { Injection } \\
\text { Temperature } \\
\left({ }^{\circ} \mathrm{C}\right)\end{array}$ & $\begin{array}{c}\text { Injection } \\
\text { Pressure } \\
\text { (MPa) }\end{array}$ & $\begin{array}{c}\text { Mould } \\
\text { Temperature } \\
\left({ }^{\circ} \mathrm{C}\right)\end{array}$ & R1 & $\mathbf{R 2}$ \\
\hline 180 & 64 & 60 & 5.0613 & 5.0259 \\
\hline 180 & 64 & 60 & 5.0867 & 5.0977 \\
\hline 180 & 64 & 80 & 5.0791 & 5.0349 \\
\hline 180 & 64 & 80 & 4.9193 & 4.9722 \\
\hline 200 & 97 & 60 & 4.9871 & 5.0154 \\
\hline 200 & 97 & 60 & 5.0186 & 5.0305 \\
\hline 200 & 97 & 80 & 4.473 & 4.2613 \\
\hline 200 & 97 & 80 & 4.1486 & 4.04 \\
\hline 180 & 97 & 60 & 5.0332 & 4.9935 \\
\hline 180 & 97 & 60 & 5.0225 & 5.0395 \\
\hline 180 & 97 & 80 & 5.0341 & 4.9016 \\
\hline 180 & 97 & 80 & 5.0053 & 5.0099 \\
\hline 200 & 64 & 60 & 5.0454 & 4.9821 \\
\hline 200 & 64 & 60 & 5.0128 & 5.0118 \\
\hline 200 & 64 & 80 & 5.0944 & 5.0625 \\
\hline 200 & 64 & 80 & 5.0673 & 5.0602 \\
\hline
\end{tabular}

Table 5: Experimental layout of Taguchi $\left(L_{16}\right)$

\begin{tabular}{|c|c|c|c|c|c|c|c|}
\hline \multicolumn{3}{|c|}{ Factors } & \multirow[b]{2}{*}{$\begin{array}{l}\text { Mean } \\
(\bar{y})\end{array}$} & \multirow[b]{2}{*}{$\begin{array}{l}\text { Std Dev } \\
\left(\mathrm{s}_{\mathrm{N}-1}\right)\end{array}$} & \multirow[b]{2}{*}{$\bar{y}^{2}$} & \multirow[b]{2}{*}{$\left(\mathrm{s}_{\mathrm{N}-1}\right)^{2}$} & \multirow[b]{2}{*}{$\mathrm{S} / \mathrm{N}$ ratio } \\
\hline $\begin{array}{c}\text { Injection } \\
\text { Temperature }\left({ }^{\circ} \mathrm{C}\right)\end{array}$ & $\begin{array}{c}\text { Injection } \\
\text { Pressure } \\
(\%)\end{array}$ & $\begin{array}{c}\text { Mould } \\
\text { Temperature } \\
\left({ }^{\circ} \mathrm{C}\right)\end{array}$ & & & & & \\
\hline 180 & 64 & 60 & 5.0436 & 0.01251579 & 25.44 & 0.000157 & 52.11 \\
\hline 180 & 64 & 60 & 5.0922 & 0.003889087 & 25.93 & 0.000015 & 62.34 \\
\hline 180 & 64 & 80 & 5.057 & 0.01562706 & 25.57 & 0.000244 & 50.20 \\
\hline 180 & 64 & 80 & 4.94575 & 0.018702974 & 24.46 & 0.000350 & 48.45 \\
\hline 200 & 97 & 60 & 5.00125 & 0.010005561 & 25.01 & 0.000100 & 53.98 \\
\hline 200 & 97 & 60 & 5.02455 & 0.004207285 & 25.25 & 0.000018 & 61.54 \\
\hline 200 & 97 & 80 & 4.36715 & 0.074847253 & 19.07 & 0.005602 & 35.32 \\
\hline 200 & 97 & 80 & 4.0943 & 0.038395898 & 16.76 & 0.001474 & 40.56 \\
\hline 180 & 97 & 60 & 5.01335 & 0.01403607 & 25.13 & 0.000197 & 51.06 \\
\hline 180 & 97 & 60 & 5.031 & 0.006010408 & 25.31 & 0.000036 & 58.46 \\
\hline 180 & 97 & 80 & 4.96785 & 0.046845824 & 24.68 & 0.002195 & 40.51 \\
\hline 180 & 97 & 80 & 5.0076 & 0.001626346 & 25.08 & 0.000003 & 69.77 \\
\hline 200 & 64 & 60 & 5.01375 & 0.02237993 & 25.14 & 0.000501 & 47.01 \\
\hline 200 & 64 & 60 & 5.0123 & 0.000353553 & 25.12 & 0.000000 & 83.03 \\
\hline 200 & 64 & 80 & 5.07845 & 0.011278353 & 25.79 & 0.000127 & 53.07 \\
\hline 200 & 64 & 80 & 5.06375 & 0.002510229 & 25.64 & 0.000006 & 66.10 \\
\hline \multicolumn{3}{|c|}{ Total } & 4.925866 & & 24.26 & & 54.59 \\
\hline
\end{tabular}




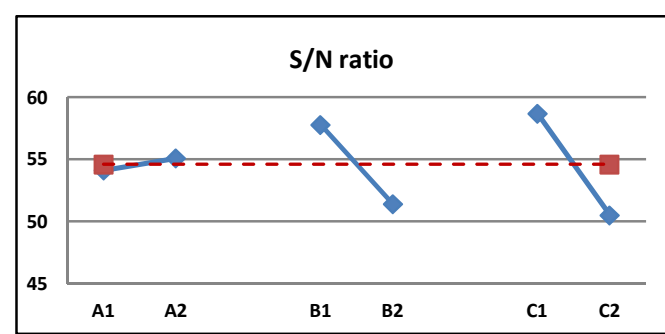

(a)

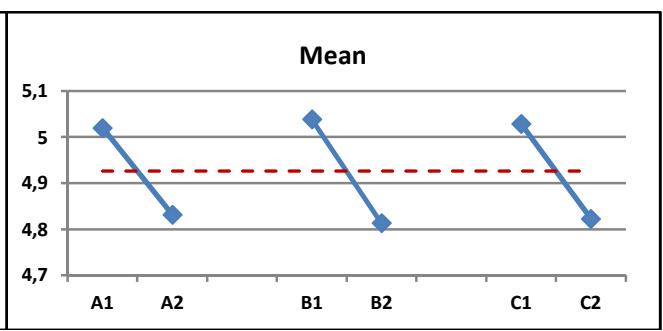

(b)

Figure 2: Response graph of (a) $\mathrm{S} / \mathrm{N}$ ratio (b) Mean ratio

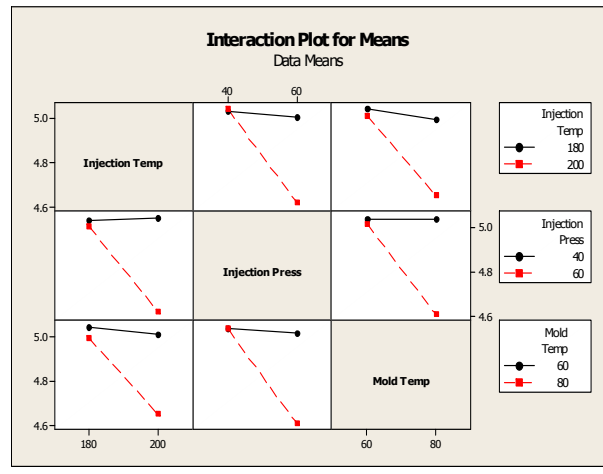

(a)

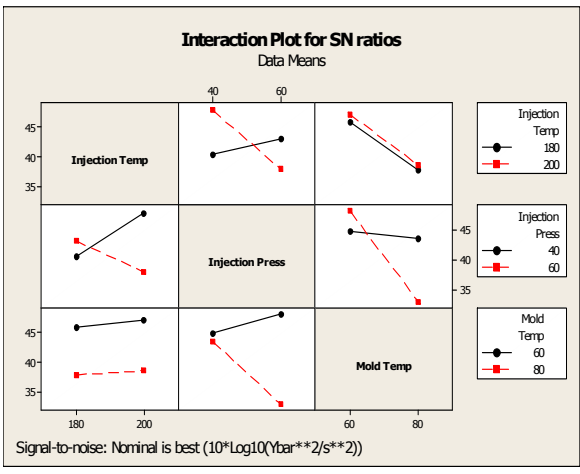

(b)

Figure 3: Factor interaction graph for (a) $\mathrm{S} / \mathrm{N}$ ratios (b) Mean ratios

\subsection{RESUlts AND DisCuSSION}

3.1 Interpretation of response table and graph

Table 6: Response table $\mathrm{S} / \mathrm{N}$ variability analysis

\begin{tabular}{cccc}
\hline & A & B & C \\
\hline Level 1 & 54.11 & 57.79 & 58.69 \\
Level 2 & 55.07 & 51.40 & 50.50 \\
Delta & 0.96 & 6.39 & 8.19 \\
\hline
\end{tabular}

Table 7: Response table Mean analysis

\begin{tabular}{cccc}
\hline & A & B & C \\
\hline Level 1 & 5.02 & 5.04 & 5.03 \\
Level 2 & 4.83 & 4.81 & 4.82 \\
Delta & 0.19 & 0.22 & 0.21 \\
\hline
\end{tabular}

Response table 7 and 8 was created by calculating the levels average for each factor level. Sample of calculation shown is the average $\mathrm{S} / \mathrm{N}$ ratio and Mean ratio for injection temperature.

$$
\begin{aligned}
\frac{\mathrm{S}}{\mathrm{N}} \text { ratio } & =\frac{(52.11+62.34+50.20+48.45+51.06+58.46+40.51+69.77)}{8} \\
\operatorname{Mean}(\overline{\mathrm{y}}) & =\frac{(5.0436+5.0922+5.057+4.94575+5.01335+5.031+4.96785+5.0076)}{8}
\end{aligned}
$$

The largest the delta or differences between the level contribute to the more significant of the factor to the density of the injected part. It can be seen in Fig. 7 that the largest difference of $\mathrm{S} / \mathrm{N}$ ratio is $\mathrm{C}$ which is mould temperature factor following the Mould and pressure and injection temperature accordingly.

Interaction between the factors also being analysed shown in Fig. 8 where it seem that factor Injection temperature and pressure have a significant interaction for both $\mathrm{S} / \mathrm{N}$ ratio and Means where else between injection and mould temperature insignificant interactions happen where the line are almost parallel which indicates that mould temperature produces higher $\mathrm{S} / \mathrm{N}$ ratio compare 
to injection temperature. Significant effect of mould temperature on pressure are noticed from the intercepted line of the $\mathrm{S} / \mathrm{N}$ graph which indicated that this factor cannot be ignored in the process.

\subsection{Optimise and Predict}

Form Fig. 2, the control factor levels that can maximise the $\mathrm{S} / \mathrm{N}$ ratio of the process is $\mathrm{A} 2$, $\mathrm{B} 1$ and $\mathrm{C} 1$ which are $200^{\circ} \mathrm{C}, 40 \%$ and $60{ }^{\circ} \mathrm{C}$. Evaluated on the $\mathrm{S} / \mathrm{N}$ ratio graph is not enough since Mean adjusting factor also need to adjusted for achieving the target value. Although the injection temperature has very little influence on $\mathrm{S} / \mathrm{N}$ ratio (see Fig. 2a), but it has the biggest impact on changing the mean production rate. Changing the temperature level might not significantly change the $\mathrm{S} / \mathrm{N}$ ratio of the process. Therefore the optimise level are changing to $180{ }^{\circ} \mathrm{C}, 40 \%$ and $60{ }^{\circ} \mathrm{C}$ and predicting $\mathrm{S} / \mathrm{N}$ ratio value is:

$$
\begin{gathered}
\frac{S}{N}=54.59+(54.11-54.59)+(57.79-54.59)+(58.69-54.59) \\
\frac{S}{N}=61.51 d B
\end{gathered}
$$

\subsection{SUMMARY}

This paper summarizes experimental investigations on optimising the green density of injected mould of stainless steel powder compounded with sewage fat and polypropylene. Taguchi method has been used in optimising the process parameter and been found that the best injection temperature is $180^{\circ} \mathrm{C}$, injection pressure of $40 \%$ and mould temperature of $60^{\circ} \mathrm{C}$

\subsection{REFERENCES}

[1] G. H. Brandtland, "Unite Nation Report of the World Commission on Environment and Development (Our Common Future)," 1987.

[2] L. Smith and P. Ball, "Steps towards sustainable manufacturing through modelling material, energy and waste flows," Int. J. Prod. Econ., vol. 140, no. 1, pp. 227-238, Nov. 2012.

[3] H. Abolhasani and N. Muhamad, "A new starch-based binder for metal injection molding," $J$. Mater. Process. Technol., vol. 210, no. 6-7, pp. 961-968, Apr. 2010.

[4] M. Afian, I. Subuki, and N. Abdullah, "The Influence Of Palm Stearin Content On The Rheological Behaviour Of 316L Stainless Steel Mim Compact,” J. Sci. Technol., pp. 1-14, 2012.

[5] S. Ahn, S. Jin, S. Lee, S. V Atre, and R. M. German, "Effect of powders and binders on material properties and molding parameters in iron and stainless steel powder injection molding process," Powder Technol., vol. 193, no. 2, pp. 162-169, 2009.

[6] M. H. . M. H. I. Ibrahim, N. Muhamad, A. A. . B. Sulong, K. . K. R. Jamaludin, N. H. . N. H. M. Nor, and S. Ahmad, "Single Performance Optimization of Micro Metal Injection Molding for the Highest Green Strength by Using Taguchi Method," J. Adv. Mater. Res., vol. c, no. C, pp. 129-134, 2011.

[7] Y. S. Zu and S. T. Lin, "Optimizing the mechanical properties of injection molded W-4 . $9 \%$ Ni-2 . $1 \%$ Fe in debinding," vol. 6, pp. 1-6, 1996.

[8] N. H. Loh and R. M. German, "Statistical analysis of shrinkage variation for powder injection molding," J. Mater. Process. Technol., vol. 59, no. 3, pp. 278-284, May 1996.

[9] A. K. Sood, R. K. Ohdar, and S. S. Mahapatra, "Improving dimensional accuracy of Fused Deposition Modelling processed part using grey Taguchi method," Mater. Des., vol. 30, no. 10, pp. 4243-4252, Dec. 2009.

[10] A. M. Amin, M. H. I. Ibrahim, and R. Asmawi, "Mixing Homogeneity and Rheological Characterization for Optimal Binder Formulation for Metal Injection Moulding," Appl. Mech. Mater., vol. 607, pp. 181-184, Jul. 2014. 